\title{
Introduction to Vol. 150 of Ophthalmologica
}

This is the 150th volume of a scientific journal which was first published in 1899 under the title "Zeitschrift für Augenheilkunde -Journal of Ophthalmology". It was launched by H. Kuhnt and /. von Michel, who found in S. Karger, Berlin, a very competent publisher for their new periodical. His successors-his son, Dr. Heinz Karger, and his grandson, Thomas Karger-have since made every effort to maintain the standard of the journal at a very high level. The "Journal of Ophthalmology" soon became well known not only in Germany but also in other countries. The initial editors were followed by /. Meller (as from 1922) and C. Behr (as from 1925). The circumstances which obliged the publishing house Karger to move from Berlin to Basel brought about the change of this journal from a German periodical to an international one which henceforth included papers in English, German and French and received the title OPHTHALMOLOGICA.

In 1938 the editorship was taken over by A. Bruckner, Basel, and H. J. M. Weve, Utrecht; in spite of his 88 years, A. Bruckner still put his great experience at the disposal of the journal even today.

It was hoped that the publication of the journal on an international basis would increase the possibilities for an exchange of scientific knowledge across linguistic and political borders and give the scientists of all countries a chance of presenting the results of their research work to as large as possible a circle of colleagues. We are pleased to state that this purpose was attained: the journal has now a world-wide distribution and serves the interchange of ideas and the friendly collaboration between ophthalmologists of various nations.

Even during the difficult years, papers from authors of occupied countries were accepted, who otherwise would not have had an opportunity of publishing their work.

The selection of suitable manuscript is one of our major tasks. To our great regret we are compelled sometimes to reject inter-

Ophthalmologica, Vol. 150, No. 1 (1965)

1

\section{i}

esting papers on account of their excessive length. As a matter of principle, only short but concise articles are published.

A few years ago OPHTHALMOLOGİCA became the official organ of publication of the Swiss and the Dutch Ophthalmological Societies.

OPHTHALMOLOGİCA is highly thought of everywhere, which is an incentive to editors and publishers alike not to relent in their efforts to further improve the journal and to render it still more attractive to its many readers.

October 1960 E. B. Streiff

Zum Erscheinen des 150. Bandes der Ophthalmologica

I. In diesem Jahr 1965 erscheint der 150. Band einer wissen-schaftliehen Zeitschrift die 1899 unter dem Namen «Zeitschrift fur Augenheilkunde» zum erstenmal herausgekommen ist. Begründer der Zeitschrift waren H. Kuhnt und /. von Michel 
die in S. Karger (Berlin) nicht nur einen Verleger voller Verständnis fanden

sondern auch einen Menschen

der das Glück gehabt hat

in seinem Sohn Heinz und seinem Enkel Thomas Karger Nachfolger zu haben

die bestrebt waren

die Zeitschrift auf einem hohen Niveau zu halten. Bald errang sich die «Zeitschrift für Augenheilkunde» ein hohes Ansehen nicht nur in Deutschland

sondern auch in vielen anderen Ländern. Als Nachfolger der Gründer übernahmen J.Meller (seit 1922) und C.Behr (seit 1925) die Redaktion. Die Umstände

welche die Übersiedelung des Verlages Karger von Berlin nach Basel veranlaßten

führten zur Umwandlung der deut-schen Zeitschrift in eine Internationale: Sie bekam den Namen OPHTHALMOLOGİCA und publizierte Arbeiten in deutscher

eng-lischer und französischer Sprache. Die Redaktion wurde im Jahre 1938 von A. Bruckner

(Basel) und H. J. M. Weve (Utrecht) über-nommen; ersterer stellt ihr auch heute noch

trotz seiner 88 Jahre

seine Erfahrung zur Verfügung.

Die Umgestaltung der Zeitschrift sollte dazu dienen

über die sprachlichen und politischen Grenzen hinweg den Austausch wissen- 